\title{
COMPARATIVE STUDY ON DISCOURSE ANALYSIS BASED ON SCHOOL'S SLOGAN
}

\author{
Djainal Yulina Tiwery \\ yulinatiwerykiryoma@gmail.com \\ English Postgraduate Study Program \\ Pattimura University Ambon
}

\begin{abstract}
The research was aimed to describe and to analyze the meanings of each slogan used in schools. To conduct the research, the researchers used descriptive qualitative method. The subjects of this research were the slogans from 4 different schools were SMP 19, SMK 2, SMK 6 and SMK 7 in Ambon city. The data was taken in the form of phrase, clause and sentence. In collecting the data, the researchers used a documentation technique by taking the pictures of the schools' slogans from those schools above. To analyze the meaning of each slogan, the researchers used pragmatic analysis especially speech act theory. The result showed that there were 5 types of slogan which applied into 14 slogans. From the total number of schools' slogans, 7 slogans were written in English and 7 slogans too were written in Bahasa Indonesia. 5 slogans contained representative meaning, 5 slogans contained directive meaning, 2 slogans contained commissive meaning, 1 slogan contained expressive meaning and 1 last slogan contained declarative meaning. Types of slogan that most used in the schools were representative and directive meanings.
\end{abstract}

Key words: School slogan, speech act

\section{Introduction}

Proper and good education is very important for all of us. It facilitates quality learning all through the life among students of any age group, cast, creed, religion and region. It is the process of achieving knowledge, values, skills, beliefs, and moral habits. That's why, students need to get high level awareness about the importance of knowledge more than before. It refers to how every educational institution is able to promote and to implement character building for students so they will have both knowledge and characters. In the very beginning, teachers must provide times for students to start thinking about inspirational ideas and then ask to create a written form of it in order to support its content. The way the teachers do is called slogan creation.

According to Cambridge Dictionary, slogan is a short easily remembered phrase, especially one used to advertise an idea or a product. So, it can be said that slogan is a sentence or phrase that expresses an idea, aim or purpose. The purpose of School slogans is to bring the students, teachers, all stuff together to inspire them with a short meaningful slogan which is whether related to life or education. School slogans especially, focus the mind on important principles, standards and ethics. Those drive people in a school community to live in harmony and achieve educational success So, slogan at school is a pivotal thing because it is used to 
promote students' character building and encourage them to think wisely about their existence, their environment, and even the world that refers to real actions in the future.

Slogan starts from a small idea to a broad impact. That is why, nowadays many schools apply school slogan because in addition to use decorate the school environment, the slogan can show up the value of life. For example, schools in Ambon city. In implementation of teaching, teachers ask students to make projects that relate to the subject they get at a certain semester. So, when we come to a school in this city, we perhaps get inspiration that is caused by what we see around the school's environment inside or outside the class. As the researchers found, slogan is not only written into English but into Bahasa Indonesia too. This condition encourages the researchers to know more about slogan's function for those schools and to do it, the researchers will analyze those slogans to find the speech act meaning of each slogan. Speech act is defined by John Austin which then used by Searle in his theory. So, Searle mostly focus on illocutionary. Illocutionary act is the act of doing something and school slogans containing it.

\section{Relevant Previous Study}

The relevant previous study about Speech Act analysis on slogan was written by Natalia Masela from Pattimura University, Ambon in 2016. Natalia collected 15 slogans from four different schools which were SD Negeri 2 Ambon, SMP Negeri 3 Leihitu and SMP Santo Andreas Ambon. She found that 4 slogans had representative meaning, 5 slogans had directive meaning, two slogans had commissive meaning, two slogans had expressive meaning and 2 last slogans had declarative meaning. From the total, 10 slogans were written in English and 5 slogans were written in Bahasa Indonesia. The researcher analyzed those slogans through speech act meaning using descriptive qualitative method.

\section{Research Question}

The researchers then formulate the research question as follows:

1. What types of speech act meaning used in 14 school slogans?

\section{The Purpose Of The Research}

The purpose of the study is written as follows: To show and to analyze the types of speech act meaning used in 14 school slogans

\section{The Definition Of Slogan}

According to a Psychologist, Muzafer Sherif states that "slogans to be a phrase, a short sentence, a headline, a dictum, which, intentionally or unintentionally, amounts to an appeal to the person who is exposed to it to buy some article, to revive or strengthen an already well-established stereotype, to accept a new idea, to undertake some action, to imply a value judgment".

In his analysis Muzafer Sherif has identified the un-estimated amount of energy and power imbibed in a slogan. He was very staunch in analyzing the element of strength, unity and solidarity inscribed in a slogan to undertake a course of action. This shows the spontaneity and dynamism of a slogan. 
Richard Usborne defined a slogan as "a form of words for which memorability has been bought. It includes memorable lines and phrases, mottoes and catchwords, that standout from political campaigns and promotions with a social purpose and which may be said to have some of the force of full-blooded spirits." (In a 1964 letter to the editors of The Penguin Dictionary of Quotations).

Slogans consist basically of unconventional words or phrases that express either something new or something old in a new way. It may be flippant, irreverent, and indecorous; it could even be indecent or obscene. Its colorful metaphors are generally directed at respectability, and it is the succinct, sometimes witty, frequently impertinent social criticism that gives slogans its characteristic flavors. Slogans, then, includes not just words but words used in a special way in a certain social context. The common denominator is that all these phrases promote a cause, idea, ideology or a product. They contain universal truths or profound insights.

For Shankel and Denton, slogans are "significant symbols" of a society, defined as fittingly worded, as much as they are carefully crafted phrases or expressions that suggest actions, evoke emotional responses, and perform persuasive functions. Slogans are easy to remember. They facilitate the release of pent -up feelings and allow us to engage in polarized thinking. According to Robert Denton, slogans also function to simplify complicated ideas, express group ideology and goals, create identification, provoke violent confrontations, and fulfill hopes for the future. In this sense, slogans can be considered as a particular form of public discourse aiming to unify public thoughts and agitate public actions and reactions.

Fred L. Casnir says "Words are the primary means of persuasion, they not only affect our persuasions, attitudes, beliefs and emotions, they create a reality. Language has a major impact on all individuals and shapes their organizational reality."

Slogans tend to evolve by some strange form of osmosis and normally more than one person can genuinely lay claim to having made a contribution. In the context of sacred texts such as the Bhagavath Gita, the Mahabharata, the Ramayana, the Qur'an and the Bible, slogans are used as a means of moral persuasion. Many contemporary churches strive to attract the surrounding population by utilizing various adjectives to describe themselves. For example, words such as "exciting," "dynamic," "friendly," or "caring," are used as part of the catchy slogans designed to grab the attention of anyone who would see or listen.

\section{School Slogan}

Education is very important to all of us as it plays very important roles in our life. In order to live a better and peaceful life, we need to be educated. In this case, education transforms us completely from inside and outside by changing our mind and personality as well as improving our confidence level. It changes our life completely as it is constructive in nature. It helps a person to get knowledge and improve confidence level all through the life. One application of this perspective is slogans are provided at schools. 
Slogans at schools are very important because comprises of meaning. It can indirectly reform ideas and characters of students, teachers even all the school stuffs. In slogan, we only read words, phrases either sentences or small paragraph but those reflect to a real action of change now and in the future. Schools that promote slogans' creation will enhance students' positive character building. Beside slogans contain wise words or inspiration statement; slogans at schools also contain the vision and mission of schools. Those are important because those give impact for all elements at schools. So, what is written as slogans must have potential to inspire the readers. Slogans at schools can give different impact for students especially. The impacts are; 1) to increase students' critical thinking, 2) to develop students' creativity, 3) to drive students' culture and to create students' ownership, 4) to increase students' concern on things around them.

\section{Speech Act}

Speech act was defined by the Oxford philosopher J. L. Austin from his book How to Do Things with Words delivered at Harvard University and posthumously published in 1962. Then, speech act theory was further developed and systematized by John Searle and others and is now a well-established species of ordinary language philosophy which can be seen as a branch of pragmatics. Since the end of the 1960s Speech Act Theory (SAT) has been developed in many directions for example dispute between conventionalism and intuitionalism on the one hand, and the debate on pornography, free speech, and censorship on the other.

\section{Speech Act Theory According To John Austin}

Austin's most celebrated contribution to contemporary philosophy is his theory of speech acts, presented in How to Do Things with Words (Austin 1975). While for philosophers interested mainly in formal languages the main function of language is describing reality, representing states of affairs and making assertions about the world, for Austin our utterances have a variety of different uses. A similar point is made in Philosophical Investigations by Wittgenstein, who underlines the "countless" uses we may put our sentences to (Wittgenstein 1953: $\S$ 23). Austin contrasts the "desperate" Wittgensteinian image of the countless uses of language with his accurate catalogue of the various speech acts we may perform - a taxonomy similar to the one employed by an entomologist trying to classify the many (but not countless) species of beetles.

Not all utterances, then, are assertions concerning states of affairs. Take Austin's examples

(1) I name this ship the 'Queen Elisabeth' as uttered in the course of the launching of a ship, or

(2) I bet you sixpence it will rain tomorrow.

The utterer of (1) or (2) is not describing the launching ceremony or a bet, but doing it. By uttering these sentences we bring about new facts, "as distinguished from producing consequences in the sense of bringing about states of affairs in the 'normal' way, that is, changes in the natural course of events" 
(Austin 1975: 117): by uttering (1) or (2) we modify the social reality, institute new conventions, and undertake obligations.

In the first lessons of How to Do Things with Words, Austin traces a tentative distinction between constatives and performatives, to be abandoned in the subsequent lessons. Constatives, on the one hand, are sentences like:

\section{(3) The cat is on the mat:}

According to Austin it is possible and fruitful to shed light on standard cases of successful communication, and to specify the conditions for the smooth functioning of a performative, by focusing on non-standard cases and communicative failures. As we have said, performatives cannot be assessed as true or false, but they are subject to different types of invalidity or failure, called "infelicities." In some cases, the attempt to perform an act fails or "misfires." The act is "null and void" on the basis of the violation of two kinds of rules:

\section{A.1: there must exist an accepted conventional procedure having a certain conventional effect, that procedure to include the uttering of certain words by certain persons in certain circumstances; \\ A.2: that procedure must be invoked in adequate circumstances and by appropriate persons.}

Further, infelicities concern the execution of the procedure, for it must be executed by all participants both:

\section{B.1: correctly, and \\ B.2: completely.}

Finally, there are cases in which the performance of an act is achieved, but there is an abuse of the procedure, due to the violation of two kinds of rules:

\section{C.1: the procedure must be executed by the speaker with appropriate thoughts, feelings or intentions;}

\section{C.2: the participants must subsequently conduct themselves in accordance with the procedure performed.}

As it is said in How to Do Things with Words Austin draws the distinction between constatives and performatives merely as a preliminary to the presentation of his main thesis, namely that there is a performative dimension in any use of language. The putative class of performatives seems to admit only specific verbs (like to promise, to bet, to apologize, to order), all in the first-person singular present. Any attempt to characterize the class with grammatical or lexical criteria, however, is bound to fail. The example of explicit performative is written below:

\section{(4) I order you to close the door}

but also, with 


\section{(5) Close the door!}

Similarly, there are performative verbs also for acts of stating, asserting, or concluding, as in:

\section{(6) I assert that the Earth is flat.}

The very distinction between utterances assessable along the dimension of truth and falsehood (constatives) and utterances assessable along the dimension of felicity or infelicity (performatives) is a mere illusion. To show this, Austin presents two arguments:

a) on the one hand, constatives may be assessed as happy or unhappy: like performatives, assertions require appropriate conditions for their felicitous performance (to give an example, it does not seem appropriate to make an assertion one does not believe);

b) on the other hand, performatives may be assessed in terms of truth and falsehood, or in terms of some conformity to the facts: of a verdict we say that it is fair or unfair, of a piece of advice that it is good or bad, of praise that it is deserved or not.

By a) and b) Austin is led to the conclusion that the distinction between constatives and performatives is inadequate: all sentences are tools we use in order to do something - to say something is always to do something. Therefore, it is necessary to develop a general theory of the uses of language and of the acts we perform by uttering a sentence: a general theory of what Austin calls illocutionary force.

Within the same total speech act Austin distinguishes three different acts: locutionary, illocutionary and perlocutionary.

- The locutionary act is the act of saying something, the act of uttering certain expressions, well-formed from a syntactic point of view and meaningful. It may furthermore be analyzed into a phonetic act (the act of uttering certain noises), a phatic act (the act of uttering words, that is, sounds as conforming to a certain vocabulary and grammar), and a rhetic act (the act of using these words with a certain meaning - sense or reference).

- To perform a locutionary act is also and eo ipso to perform an illocutionary act (Austin 1975, 98). An illocutionary act is a way of using language, and its performance is the performance of an act in saying something as opposed to performance of an act of saying something. It corresponds to the force that an utterance like (5) has in a particular context: order, request, entreaty, or challenge.

- The perlocutionary act corresponds to the effects brought about by performing an illocutionary act, to its consequences (intentional or nonintentional) on the feelings, thoughts, or actions of the participants. According to Austin the speaker, by saying what she says, performs 
another kind of act (like persuading, convincing, or alerting) because she can be taken as responsible for those effects (compare Sbisa 2006 and 2013). Yet the perlocutionary consequences of illocutionary acts are nonconventional, not being completely under the speaker's control, but rather related to the specific circumstances in which the act is performed. Austin makes a further distinction between perlocutionary objects (the consequences brought about by an illocutionary act in virtue of its force as alerting can be a consequence of the illocutionary act of warning) and perlocutionary sequels (the consequences brought about by an illocutionary act without a systematic connection to its force - as surprising can be a consequence of the illocutionary act of asserting) (Austin 1975: 118).

\section{Speech Act Theory According To Searle}

As stated above that Austin analyzes the utterance from performative utterance into illocutionary act. However, in this case, Searle tries to analyze the utterance form different perspective. Searle (1969:21) resists the idea that conversation is governed by constitutive rules. In this case, Searle proposes that the speech act is the basic unit of communication. This view places speech act at the very crux of the study of the language, meaning, and communication. Thus, viewing speech acts as the basic unit of communication allows Searle to explicitly associate speech act with the study of language: its production, its interpretation; meaning (both speaker meaning and linguistics meaning); there are a series of analytic connections between the notion of speech acts, means, what the speaker means, what the sentence (linguistic element) uttered means, what the speaker intends, what the hearer understand, and what the rules governing the linguistic elements are.

Based on the explanation above, it can be noted speech acts are part of linguistic competence: language can be used for speech act because people share rules that create the acts that say what is meant. Searle observes that "speaking a language is engaging in a rule-governed from form of behavior". The rule that is responsible for speech acts is constitutive. It means that constitutive rules "create or define new forms of behavior". In contrast to regulative rules is that regulate independently existing forms of behavior. The forms of the two types of rules reflect their different status: regulative rules are expressed as imperatives, but constitutive rules are more definitional. Searle's rules and conditions for speech draw upon both context and text. Searle classifies condition and rules according to their necessity for the act. In this case, Searle classifies different kinds of conditions and rules according to what aspect of text and context is focused upon in the condition or rule.

Furthermore, Searle's ideas and Austin has the same concept on utterance. The uttering of words (morpheme and sentences) is an utterance act. Referring and predicating are propositional acts. Acts like stating, questioning, commanding, and promising are illocutionary acts. Illocutionary acts are what are constituted by the rules note above. In addition, they have a name, and they are what the speaker(S) is doing, in relation to the hearer $(\mathrm{H})$ with words. The 
consequences of illocutionary acts (the effects on action, thought, beliefs of hearers) are perlocutionary acts.

In analyzing the utterance, Austin' framework focuses on performative verb, while Searle focuses on subject to the condition and rule. Here, Searle presents the rules for requests, assertions, questions, thanks, advising, warnings, greetings, and congratulating. Propositional content conditions or rules are most textual. It means that they concern with reference and predication of a future act by the speaker. Preparatory conditions or rules are varied; they seem to involve background circumstances and knowledge about $\mathrm{S}$ and $\mathrm{H}$ that must hold prior to the performance of the act. In this case, the preparatory condition for promise, for example, concerns H's preference about S's doing of an act (A). Consequently, each rule focuses only upon the textual content, preparatory rules focuses upon background circumstances, the sincerity rule upon S's psychological state, and the essential rule upon the illocutionary point what is said. Searle finds that different conditions or rules are more or less crucial to the non-defective performance of an act (1969:54).

In sum, Searle places the speech act at the center of the study of language, meaning, and communication: he proposes that "the basic unit of human linguistic communication is the illocutionary act (Searle: 1979:1). It can be analyzed the semantic structure of a language may be regarded as conventional realization of series of sets of underlying constitutive rules and speech acts are the acts characteristically performed by uttering expressions in accordance with these sets of constitutive rules. So, utterances performed different acts because of their "circumstances" (Austin) and because of the knowledge that we have of the conditions and rules that constitute particular acts (Searle).

\section{Speech Act Classification}

Speech acts according to Austin (1962) fall into three classes, which are: locutionary, illocutionary and perlocutionary acts.

1. A locutionary act is an act of saying something; that is, the act of producing an utterance.

2. Illocutionary acts are the core of any theory of speech acts.

3. Perculotionary act is the effect or influence on the feelings, thoughts or actions of the listener/hearer unlike locutionary acts. Perlocutionary acts could be inspiring, persuading, consoling, promising, encouraging etc. It brings about an effect upon the beliefs, attitudes or behaviours of the addressee. It is in consonance with this that Levinson (1981) describes perlocutionary act as the intended or unintended consequences of the speaker's utterance.

Searle (1969) improves on Austin's (1962) Speech Act theory by distinguishing between two types of speech acts: Direct and Indirect Speech Acts. Searle (1969) categorizes the illocutionary act into five classes:

1. Assertive: These are statements that describe a state of affairs in the world which could be true or false. They commit a speaker to the truth of the expressed proposition.

2. Directives: These are statements that compel or make another person's action fit the propositional element. It is usually used to give order 
thereby causing the hearer to take a particular action, request, command or advice.

3. Commissive: These statements commit the speaker to certain future action. It could be in the form of a promise.

4. Expressive: The purpose of expressive statements is to express sincerity of the speech act like excuses and sympathy.

5. Declaratives: These statements are used to say something and make it so, such as someone guilty and declaring a war.

Related to the explanation above, according to Yule (1996: 53), One general classification system lists five types of general functions performed by speech acts; declarations, representatives, expressive, directives, and commissive.

(1) Declarations, according to Yule (1996:53) declarations are those kinds of speech acts that change the world via their utterance. In this case, the speaker has to have a special institutional role in a specific context in order to perform a declaration appropriately. Therefore, declaration acts can be occurred if the speaker has a special role in a certain field. On the other way, if the speaker has not a special role in a certain field the speech acts cannot be happened. The example as follows: "Priest: I now pronounce you husband and wife". From the example, we know that the speaker has a special institutional role in the specific context as a "priest". Before the speaker declares it, a couple of man and woman have not become husband and wife. In this case, after the speaker declares that a couple of man and woman have married and now they became husband and wife).

(2) Representatives based on Yule (1996:53) representatives are those kinds of speech acts that state what the speaker believes to be the case or not. Statements that are included in representative acts are fact, assertions, conclusions, and descriptions. The example as follows: the speaker says "Today is so cool". From the example, the utterance "today is so cool" is representative acts by paradigm case fact because truly today is raining. Therefore, the raining makes the weather become so cool.

(3) Expressive, Yule (1996:53) states that expressive are those kinds of speech acts that state what the speaker feels. They express psychological states and can be statements of pleasure, pain, likes, dislike, joy, or sorrow. They can be caused by something the speaker does or the hearer does. The example as the following: the speaker says "Woooww, the hat is very beautiful". The utterance "Woooww, the hat is very beautiful" is expressive acts by paradigm case likes because the speaker wants to express about something that he or she likes. In addition, the speaker wants to show a beautiful hat that he or she likes to the hearer in order to the hearer know about what the speaker's feel.

(4) Directives, Yule (1996:54) states that directives are those kinds of speech acts that speakers use to get someone else to do something. They express what the speaker wants. The utterances that can be included in directives acts are commands, warning, requests, suggestions, and they can be positive or negative. The example as the following: the speaker says, "Would you mind to open the door, please?". The utterance "Would you mind to open the door, please?" is directive acts by paradigm case requesting. This utterance has 
intended meaning that the speaker wants to ask the hearer to open the door in order to the speaker can feel the fresh air because the weather is so hot.

(5) Commissive, based on Yule (1996:54), commissive are those kinds of speech acts that speakers use to commit themselves to some future action. They express what the speaker intends. They are promises, threats, refusals, pledges, and they can be performed by the speaker alone. The example as the following: the speaker says "After I arrived at home, I will call you". The utterance "After I arrived at home, I will call you" is commissive acts by paradigm case promises because without the speaker says "promise" to the hearer, the utterance "I will call you" has already revealed "promise" that the speaker will call the hearer to give information that the speaker has already arrived at home safely.

\section{Speech Act In Discourse Analysis}

John Searle then expanded and incorporated speech act theory into linguistic theory. Searle's work also rises important questions concerning (classification) of acts about which people know and the way that a single utterance can be associated with more than one act. Searle has proposed some terms that are commonly used such as apology, complain, compliment, invitation, promise, or request. These descriptive terms for different kinds of speech acts apply to the speakers' communicative intention in producing an utterance. The speaker normally expects that his or her communicative intention will be recognized by the hearer.

Although speech theory was not first developed as a means of analyzing discourse, some of its basic insights have been used by many scholars to solve problems basic to discourse analysis. In addition, particular issues in speech act theory lead to discourse analysis; how an utterance can perform more than one speech act at a time, and the relationship between contexts and illocution.

As a conclusion, discourse is used for communication. People use utterances to convey information and to lead each other toward an interpretation of meanings and intentions. This role greatly increases the scope of discourse analysis, simply because one has to address how the language of the utterances is related to aspects of the communication process that bear an indirect relationship to language users.

\section{Research Methodology}

The method that the researchers used to conduct the research is descrptive qualitative method. It is a research method in which it does not include any calculation or enumeration (Moleong, 2004:11). The purpose of the research is to get the systematic description of the facts and the characteristic description of the data. So according the researchers, it is an appropriate method to be used in order to assist the researchers to describe and to analyze the speech act meaning which were founded on 14 school slogans that were written in English and in Bahasa Indonesia languages.

The researchers visited 4 schools in Ambon city and they collected 14 slogans. 9 slogans were taken from SMP Negeri 19 Ambon, two slogans were 
taken from SMK 2 Ambon, one slogan was taken from SMK 6 Ambon and two slogans were taken from SMK 7 Ambon. Those slogans were written into English and Bahasa Indonesia languages.

Table 3.1 Schools' slogans

\begin{tabular}{|c|c|}
\hline Name of school & The list of slogans \\
\hline $\begin{array}{l}\text { SMP Neg. } 19 \\
\text { Ambon }\end{array}$ & $\begin{array}{l}\text { Lestarikan bumi kita karena bumi kita sangat luas } \\
\text { dengan kelimpahannya jadi mari kita merawat dan } \\
\text { melestarikan budaya kita agar tetap terhindar dari } \\
\text { kerusakan dan mala petaka } \\
>\text { Gantungkan cita - cita setinggi mungkin jangan biarkan } \\
\text { siapapun juga menghalangi } \\
>\text { Narkoba pembunuh karaket bangsa } \\
>\text { I am strong because I know my weaknesses } \\
\text { I am beautiful because I am aware of my flaws } \\
\text { I am a lover because I have felt hate and } \\
\text { I can laugh because I known sadness } \\
>\text { Don't litter } \\
>\text { Say no to drugs } \\
>\text { Be grateful to your parents and teachers } \\
>\text { Reading is the window of the world } \\
>\text { No sex before married }\end{array}$ \\
\hline SMK 2 Ambon & $\begin{array}{l}\text { Kreatif, kompetetif, kebersamaan dan inovatif unggulan } \\
\text { kami } \\
\text { Teknik Mesin always: Discipline, friendly, polite, clean, } \\
\text { beautiful, cool, green school }\end{array}$ \\
\hline SMK 6 Ambon & D SMK 6 Ambon mengubah pasir menjadi mutiara \\
\hline SMK 7 Ambon & $\begin{array}{l}\text { Kebersihan itu sebagian dari iman dengan itu } \\
\text { membuang sampah pada tempatnya, berarti beta bisa } \\
\text { menjaga lingkungan sendiri } \\
\text { Pintar itu mahal, ayo kita belajar } \\
\text { Hari ini saya memimpin karena kemarin saya membaca }\end{array}$ \\
\hline
\end{tabular}

Documentation was the technique of collecting data (Slogans). The researchers visited 4 schools in Ambon city which were chosen randomly and asked permission from school's headmasters to take the picture of the school slogans from class to class and also from schools filed.

The researchers used and followed speech acts theory in order to describe and to analyze the meaning of 14 schools' slogans finding from 4 schools at Ambon city.

\section{Findings}

This part focuses on analyzing the speech act meaning from 14 school slogans based on the illocutionary acts' classes by John Searle.

\section{Using Speech Act To Analyze Slogans}


1. Schools' slogans written in English

a. I am strong because I know my weaknesses

I am beautiful because I am aware of my flaws

I am a lover because $I$ have felt hate and

I can laugh because I known sadness

This slogan is classified into representative meaning of speech act because all adjective from the slogan refers to subject "I" with unknown. So, the word "I" can represent someone or something that unclear for us after read it.

b. Don't litter

This slogan is classified into directive meaning of speech act because it contains an imperative phrase "Don't" as a prohibition.

c. Say no to drugs

This slogan is classified into directive meaning of speech act because it has an imperative phrase which is "Say no". The phrase can be meant as a commitment to do not do or to do not choose. The word "No" fortifies the meaning of the phrase.

d. Be grateful to your parents and teachers

This slogan is classified into expressive meaning because the phrase "Be grateful" expresses students' feeling of thank for their parents and their teachers because they do many for them.

e. Reading is the window of the world

This slogan is classified into representative meaning of speech act because it states the truth that all people in the world admit that by reading everyone can able to compete or to work wherever or everyone gets many knowledges from different sources through reading a lot of books.

f. No sex before married

This slogan is classified into directive meaning of speech act because it challenges everyone who have not married to do not do "Sex" even more for students as the future generation in our country.

g. Teknik Mesin always: Discipline, friendly, polite, clean, beautiful, cool, green school

This slogan is classified into representative meaning of speech act because those words are mentioned one by one. Machine Technique is represented by those 8 words as its identity.

2. Schools' slogans written in Bahasa Indonesia

a. Lestarikan bumi kita karena bumi kita sangat luas dengan kelimpahannya jadi mari kita merawat dan melestarikan budaya kita agar tetap terhindar dari kerusakan dan mala petaka

This slogan is classified into directive meaning of speech act because it suggests everyone to keep the nature, to keep the environment wherever in reason if not she or he will lose everything even the life when the problems happened.

b. Gantungkan cita - cita setinggi mungkin jangan biarkan siapapun juga menghalangi 
This slogan is classified into directive meaning of speech act because it challenges students to do their best to get their future and must be able to defend it so that no one to thwart it.

c. Narkoba pembunuh karakter bangsa

This slogan is classified into representative meaning of speech act because it is only saying that "Drug is the killer of nation character". Drug represents killer of nation.

d. Kreatif, kompetetif, kebersamaan dan inovatif unggulan kami

This slogan is classified into representative meaning of speech act because it mentions 4 things that being the potential of the school. This is a school motto. In concept, it motivates students to gain and to prove those 4 things as they aimed to reach successfully.

e. SMK 6 Ambon mengubah pasir menjadi mutiara

This slogan is the motto of SMK 6 Ambon. It is classified into commissive meaning of speech act because it commits the students and public about its consistency to change every student becomes worthy person in the future. And also, it promises the public about its commitment to change something becomes something if SMK 6 is chosen as the school to study at.

f. Kebersihan itu sebagian dari iman dengan itu membuang sampah pada tempatnya, berarti beta bisa menjaga lingkungan sendiri

This slogan is classified into commisive meaning of speech act because the slogan needs a treatment to do. Cleanliness is a half part of faith so when someone keeps his or her environment always clean, she or he is a faithful person as an impact to each personality.

g. Pintar itu mahal, ayo kita belajar

Hari ini saya memimpin karena kemarin saya membaca

This slogan is classified into declarative meaning of speech act because it contains cause and effect of a reality when we study hard, we will be clever and it affects out future for example get good jobs, become rich, success in everything etc. furthermore, the second line contains cause and effect too. It is said that, when we read many, we can be leaders in the future. So, this slogan decelerates a truth in the future as the result of what had done in the past.

\section{Discussion}

This part focuses to group the 14 slogans into the category of classification based on the 5 classes of illocutionary acts which were developed by John Searle.

a. Representative

Meaning : it is a speech act that commit a speaker to the truth or that bound a speaker to the truth.

Example : saying, reporting, and mentioning

Finding : there are 5 slogans that have representative meaning:

1) I am strong because I know my weaknesses

I am beautiful because I am aware of my flaws

I am a lover because I have felt hate and 
I can laugh because I known sadness

2) Reading is the window of the world

3) Narkoba pembunuh karaker bangsa

4) Kreatif, kompetetif, kebersamaan dan inovatif unggulan kami

5) Teknik Mesin always: Discipline, friendly, polite, clean, beautiful, cool, green school

\section{b. Directive}

Meaning : it is a speech act that is to cause the hearer to take a particular action.

Example : begging, suggesting, requesting and challenging

Finding : there are 5 slogans that have directive meaning:

1) Don't litter

2) Say no to drugs

3) No sex before married

4) Lestarikan bumi kita karena bumi kita sangat luas dengan kelimpahannya jadi mari kita merawat dan melestarikan budaya kita agar tetap terhindar dari kerusakan dan mala petaka

5) Gantungkan cita - cita setinggi mungkin jangan biarkan siapapun juga menghalangi

\section{c. Commissive}

action

Meaning : it is a speech act that commits a speaker to some future

Example : promising and threatening

Finding : there are 2 slogans that have commisive meaning:

1) SMK 6 Ambon mengubah pasir menjadi mutiara

2) Kebersihan itu sebagian dari iman dengan itu membuang sampah pada tempatnya, berarti beta bisa menjaga lingkungan sendiri

d. Expressive

Meaning : it is a speech act that expresses the speaker's attitudes and emotions toward proposition

Example : congratulation, excuse, and thanks

Finding : there is only 1 slogan that has expressive meaning:

1) Be grateful to your parents and teachers

e. Declarative

Meaning : it is a speech act that changes the reality in accord with the proposition of the declaration. On the other hand, it is a speech act that done by a speaker to create a new thing.

Example : baptism, pronouncing someone guilty or pronouncing someone husband of wife.

Finding : there is only 1 slogan that has declarative meaning:

1) Pintar itu mahal, ayo kita belajar

Hari ini saya memimpin karena kemarin saya membaca

\section{Conclusion}


Based on the 14 school slogans that are described and analyzed in the discussion, the researchers found that there are 5 slogans in representative meaning, 5 slogans in directive meaning, 2 slogans in commissive meaning, 1 slogan in expressive meaning and 1 slogan in declarative meaning. 7 slogans are written in English and 7 slogans are written in Bahasa Indonesia. So, it can be concluded that, from 14 slogans from 4 schools, the types of slogan that most use are representative and directive meanings. Furthermore, speech act theory leads to discourse analysis; how an utterance can perform more than one speech act at a time, and the relationship between contexts and illocution which is meant there is an action behind a sentence that is spoken or written based on the context.

\section{References}

European Journal of Social Sciences Studies. Available in www.oapub.org/soc Masela, Natalia. 2016. Comparative Study on Discourse Analysis in School Slogan. Ambon: Pattimura University

Moloeng, Lexy. 1989. Metodology penelitian Kualitatif. Jakarta: Depdikbud. In A PRAGMATIC ANALYSIS OF SLOGAN USED IN CAR ADVERTISEMENT by ASHAR WASKITO INDERAGIRI

http://www.findameaning.info/latin-mottos/school-mottos.htm retrieved in 29 Juni http://www.teentruth.net/school-slogans-school-culture/ retrieved in $30 \mathrm{Juni}$ https://www.iep.utm.edu/austin/ retrieved in $30 \mathrm{Juni}$

https://www.researchgate.net/publication/283081784_The_Language_Outside_an

d_Inside the Foreign_Language_Classroom_Speech_Act_Theory_a nd_Discourse_Analysis retrieved in 30 Juni

http://lppbi-fiba.blogspot.com/2009/10/speech-act-theory-as-approach-to.html retrieved in 1 July

http://www.dictionary.com/browse/speech-act retrieved in 1 July 